（46）遠地地震の観測

（財）鉄道総合技術研究所

中村 豊

（株）福山コンサルタント

渡辺保宣

1.はじめに

地震防災の研究には、地震そのものについての知諩が不可欠である。どのような地震動が守ろうとする施 設に作用するのか、その破壊力の大きさや作用時間は？、今どこでどのような地震が発生しようとしている のか? など知りたいことは山ほどある。地震の予知に関係するようなことはその道の専門家に委ねるとして も、地震の力学的性筫についてはある程度自身の手で㨡んでおきたい。そのために強震観測などを手掛けて いるが、大規模地震はたびたび発生するものではなく、大規模地震に関するデー夕の不足は否めない。しか し、目を世界に転じれば、大規模地震も年に 1 度や 2 度は発生している。遠くで発生した地震であるため、 日本ではきわめて小さ な地震動になっている が、大規模地震の性質 は保存されているはず である。こうした地震 を記録して、大規模地 震についての知識を少 しでも広げることがで きればと考えて、1986 年 5 月から遠地地震の 観測を始めた。これま でにアラスカ地震、台 湾の被害地震、中国の 被害地震、アルメニヤ 地震などが記録されて いる。

ここでは、記録され た遠地地震の地震動波 形に見られる 2,3 の 性筫について報告する。

2. 観湘状況 遠地地震の観測は、 $0.1 \mathrm{~Hz} \sim 20 \mathrm{~Hz}$ の測定周 波数を持つ速度出力の 地震計 (固有周期約 3 秒, 減衰定数約 40） 3 成分と $14 \mathrm{ch}$.のアナロ グデータレコーダを用 いて行っている。地震

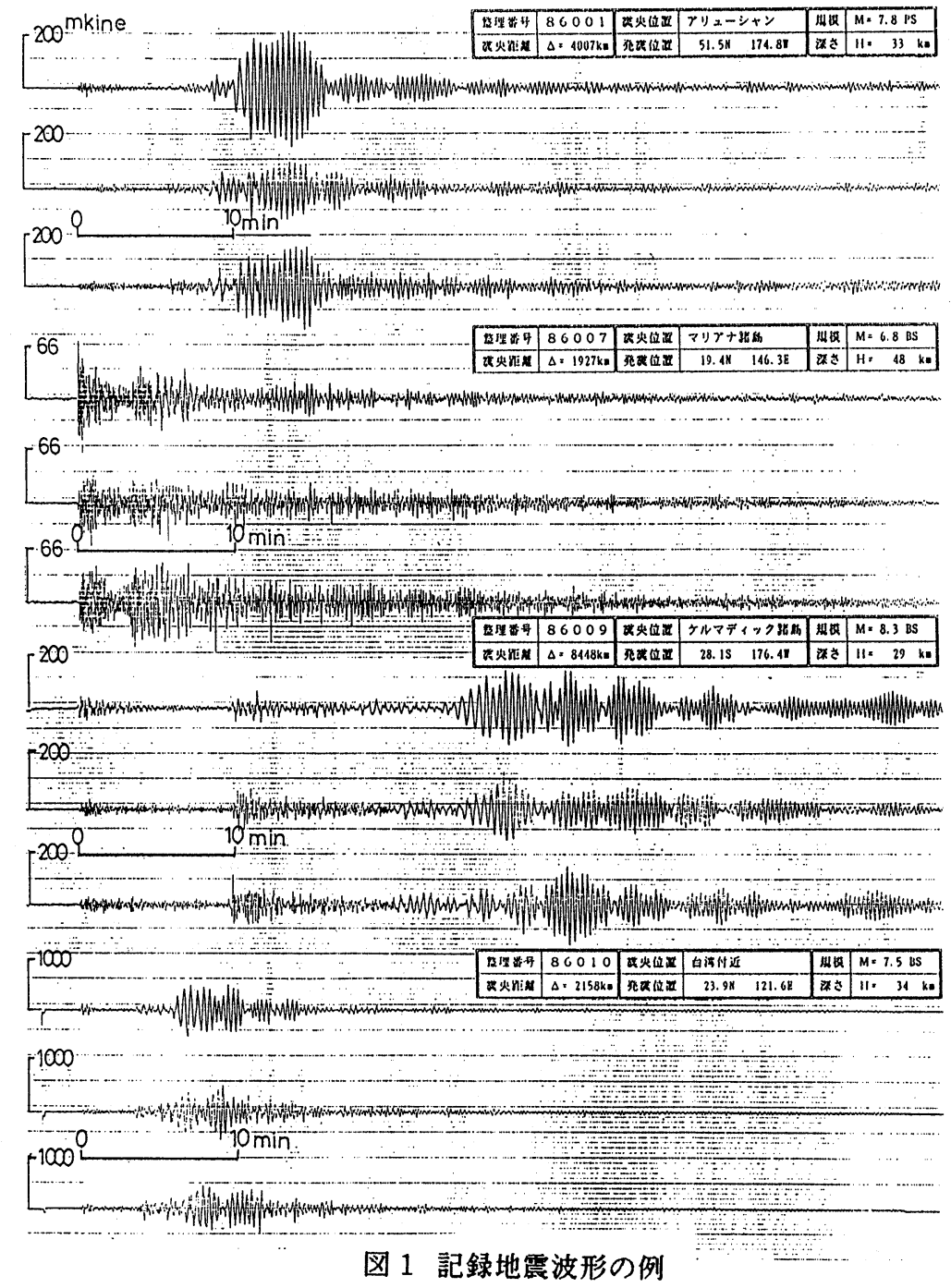


計の出力は1V/kineであるが、こ れを5倍に増幅したものも併せて フルスケールが 200mkineと200 Omkineの 2 種類の感度で記録し ている。記録は24時間連続して 行ない、毎朝記録テープを高速 再生して、地震があれば別のテ ープにダビングしている。磁気 テープの最大記録時間は 32 時 間であるので、休日等には欠測 している場合がある。

地震計の設置位置は 1986年5

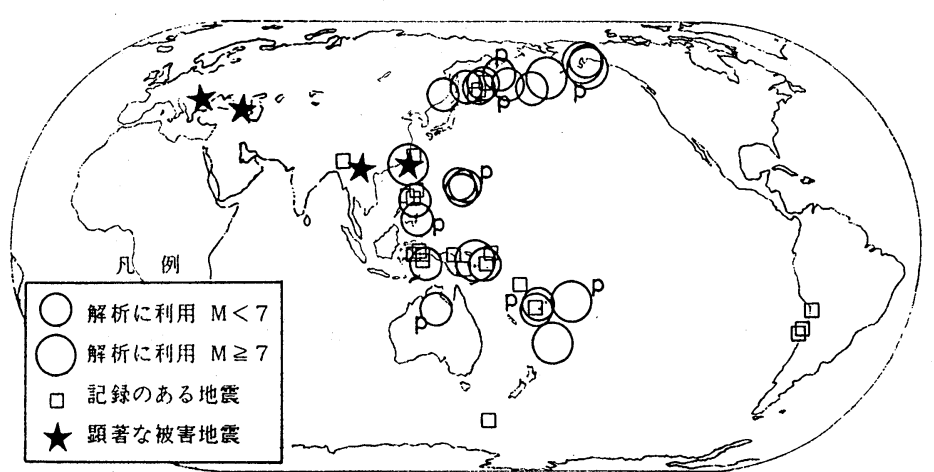

目 2 震央分布図 月の観測開始から 1988年2月までは 1 階建て建屋の床下コ ンクリート上であっ たが、それ以後深さ 約 $2 \mathrm{~m}$ に地下地震計室 を新設して移設した。 観測点周辺の表層 地盤としては、関東 ロームが約2m堆積し、 その下にはいわゆる 武蔵野碟層が約 $5 \mathrm{~m}$ 堆 積している。その下 に本地域の地震基盤 と考えられる第 3 紀 表一 1 解析対象地震りスト 上総層群が広がっている。なお、常時 微動によると、長周期側が 約4秒、単 周期側は約 $6 \mathrm{~Hz}$ が卓越している。 これまで（1989年 5月）に記録された 遠地地震は61個であるが、初動から明

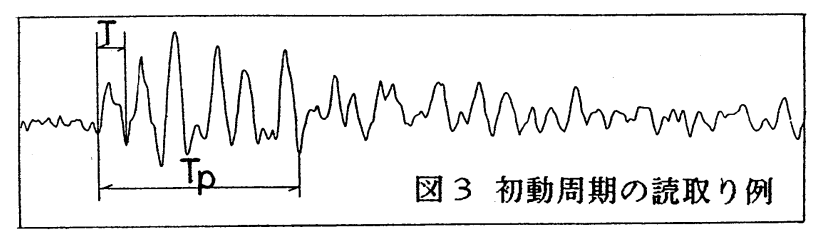
瞭に記録されている25個の地震を解析 対象とした。表 1 はこれらの地震のリストである。図 1 に記録地震波形の例を示す。図 2 はこれらの地震の 震央分布図である。図中太印で示された地震は顕著な被害地震である。

\section{3. 地震の規模と初動周期の関係}

初動周期を図 3 のように読み取り、USGSや気象庁などが決定した地震規模 Ms と対比した。図 4 はその結 果を示したものである。図中の実線はユレダス ${ }^{1} に$ 用いている $\mathrm{M}-\mathrm{T}$ 関係式を示す。これは初動周期から地 震規模Mを推定するものであるが、この式を用いた場合、地震規模Mは $\mathrm{M}_{\mathrm{s}}$ より大きめに推定されることが わかる。その推定誤差は、-1.0〜+0.2となっている。

4. 初動の波形形状について 
図 5 にいくつかの地震の $\mathrm{P}$ 波初動部分を示す。こ れにみられるようにP 波初動到着後大きな振幅が数 秒から数十秒間継続する部分が認められる。この部 分は他の部分と明確に区分できる訳ではないが、断 層破壊の様子を示したものと考元られる。また多重 震源と考えることもできる。ここでは、この部分の 震動をひとつの断層破壊に伴うものだと考えて図 3 に示したように震動の継続時間 $\mathrm{T}$ 。を読み取った。

図6 は読み取った継続時間 $\mathrm{T}$ 。と地震規模 $M$ の関 係を示したものである。継続時間 $\mathrm{T}$ 。は、断層破壊 が継続した時間と、それぞれの断層地点から観測点 までの波動の到達時刻の差が関係していると考えら れる ${ }^{21}$ 。ここでは、簡単のため $\mathrm{T}$ 。を断層破壊の継 続時間とみなして、宇津による断層の大きさ Lと $\mathrm{M}$ との関係式（logL $=0.5 \mathrm{M}-1.8 ）$ を断層破壊の伝播速

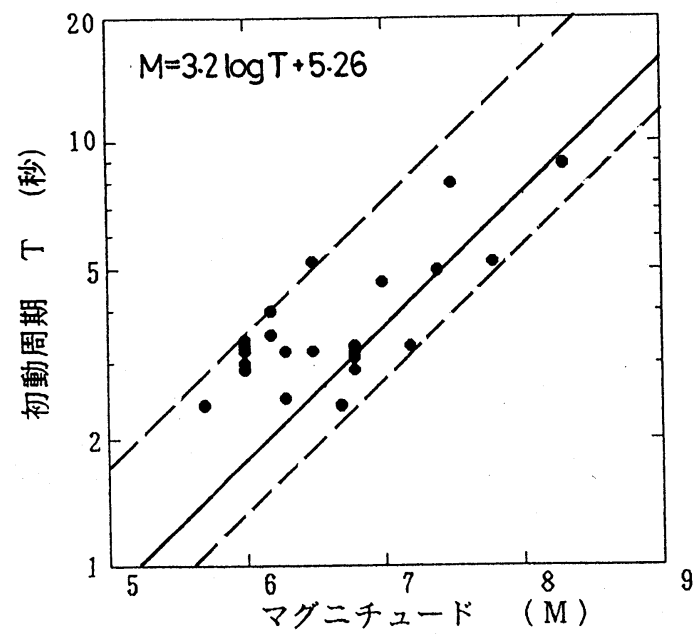

図-4 MとTの関係

度を $2.5 \mathrm{~km} / \mathrm{s}$ として求 めた断層破壊継続時間 と比較する。宇津の式 から求められた継続時 間は図 6 に実線で示さ れている。いくつかの 例外があるが、概ね実 線とデータは一致して いる。

5. 初期微動継続時間 と震央距離の関係

図 7 は初期微動継続

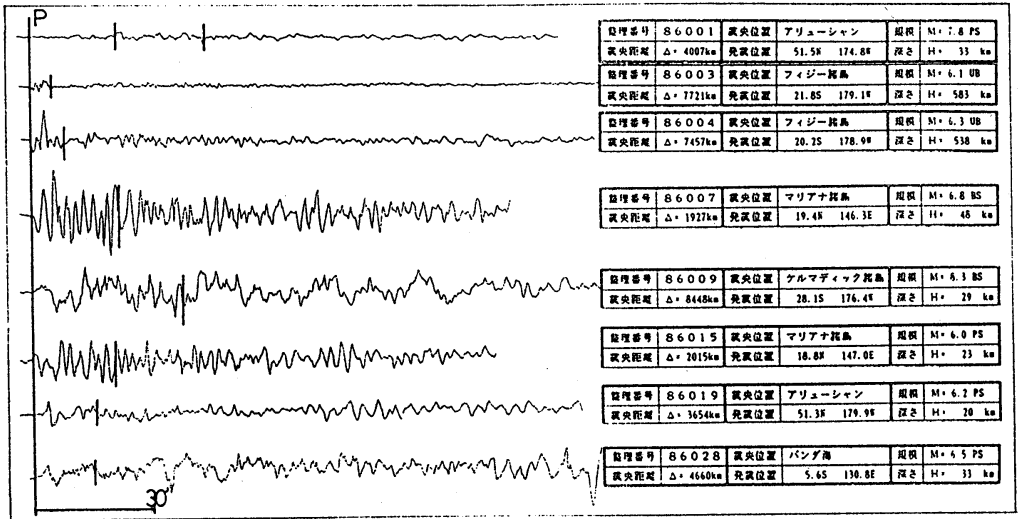

時間を読み取って震央距離と対比したものである。 震央距離が $1000 \mathrm{~km}$ 程度では、いわゆる大森係数 $\mathrm{k}$ は 約10となっているが、震央距離が大きい部分は大森 係数も大きく、15程度までになる。震央距離が 1700 $0 \mathrm{~km}$ 程度あるチリ地震の場合、初動ははっきりして いるものの後続の波動が不明瞭であった。理科年表 などに揭載されている走時曲線によれば、 $14000 \mathrm{~km}$ より遠い地震については核を通るため、かなり様子 が変わったものになることがわかる。図8 は走時曲 線に地震波形を重ねて表示したものであるが、理論 的に予想される波動の発現が観測データとよく一致 していることがわかる。またそれぞれの波動の大き さの程度が観測データにより、よく理解できる。

図 5 P 波初動の例

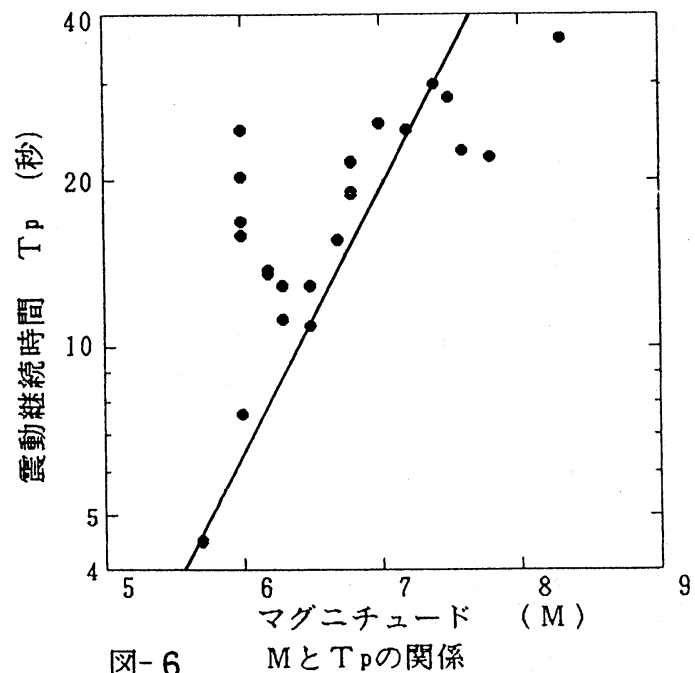




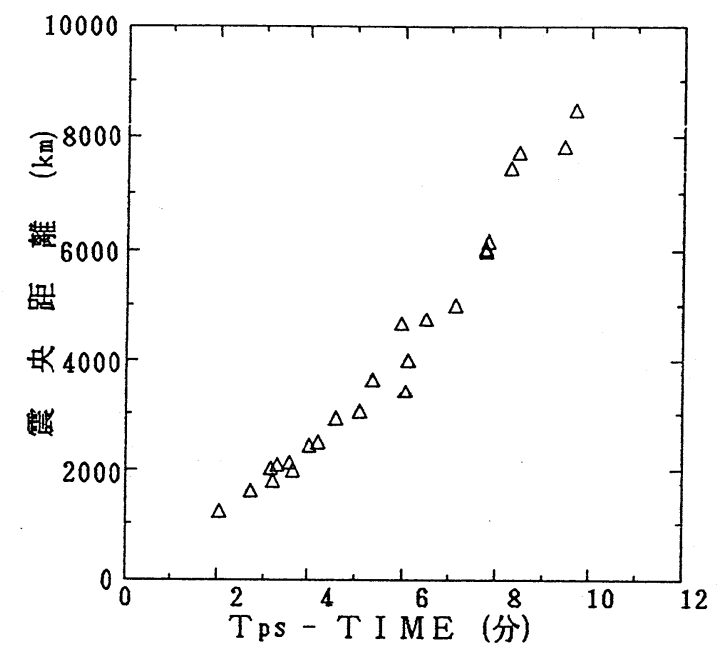

图-7 PS-TIMEと震央距離の関係

\section{6. 上下動最大速度振幅}

上下動波形をみると、 $\mathrm{P}$ 波の部分で振幅が最大に なっているものと、S波またはそれ以後の表面波の 部分で最大になっているものが認められる。P 波部 分で最大振幅になっている地震を図 2 中にPをつけ て示す。これらの震央から見た東京の観測点方位は 断層線と 45 度に近い角度になっているものと想像さ れる。

図 9 は上下動の最大速度振幅を震央距離に対して 示したもので数字はマグニチュードを表す。図中の 網掛け部分は M 7 と M 8 の地震の振幅減少程度を大 まかに示したものである。

これによると、ほぼM 7 クラス以上の地震は世界 中どこで発生してもわれわれのシステムに 10mkine 以上の地震動として捕捉されるものと考えられる。

\section{7. おわりに}

ここでは、遠地地震の記象を用いて、初動周期と 地震規模の関係、初動の波形形状、最大值などにつ いて検討した。これは遠地で発生した大地震の記録 を工学的に利用する検討の第一歩だと考えている。 今後はより詳細な解析を行い、大地震の震源特性、

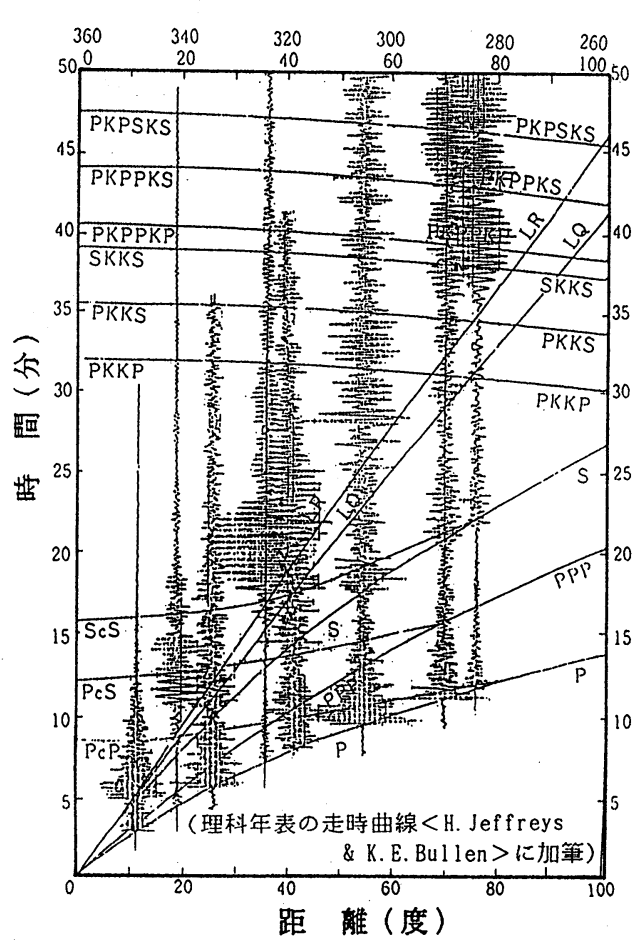

図 8 地震波形と走時曲線

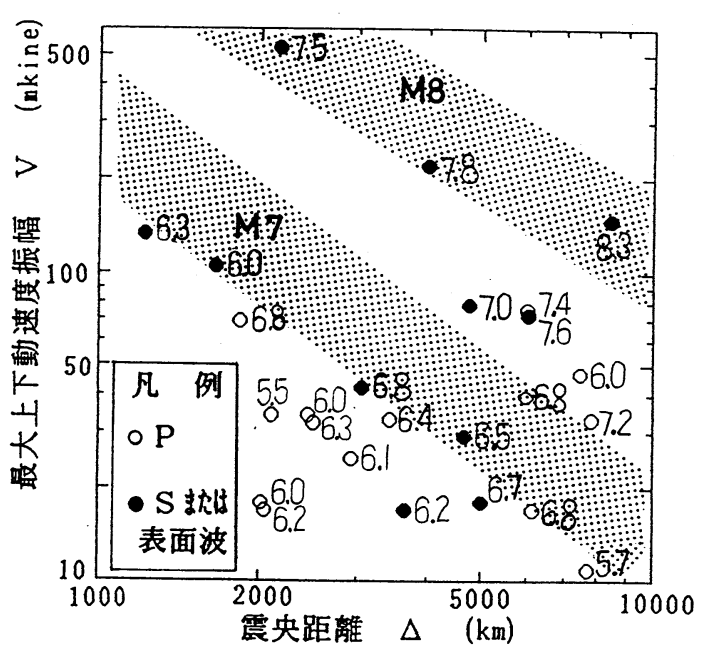

四-9 $\Delta$ と $V$ の関係

波動の発生伝播、強震動の作用時間などを検討していくとともに、一点観測に基づく太平洋沿岸の巨大地震 に対する津波警報の可能性などについても検討して行きたい。

参考文献: 1 ) NAKAMURA, Y., On The Urgent Earthquake Detection and Alarm System "UrEDAS", Proceedings of Ninth World Conference on Earthquake Engineering, VII-673 678, August 1988 .

2 ) 中村・渡辺「地震観測波形に見られる表層地盤と震源の特性」第19回地震工学研究発表会概 要集、1987年7月) 